\title{
Crenicichla $h u$, a new species of cichlid fish (Teleostei: Cichlidae) from the Paraná basin in Misiones, Argentina
}

\author{
LUBOMÍR PIÁLEK ${ }^{1}$, OLDŘICH ŘÍČAN ${ }^{1}$, JORGE CASCIOTTA ${ }^{2} \&$ ADRIANA ALMIRÓN $^{2}$ \\ ${ }^{1}$ Department of Zoology, Faculty of Science, University of South Bohemia, Branišovská 31, 370 05, České Budějovice, Czech Republic. \\ E-mail:lubomir.pialek@prf.jcu.cz,oldrichrican@yahoo.com \\ ${ }^{2}$ División Zoología Vertebrados, Museo de La Plata, UNLP, Paseo del Bosque, 1900 La Plata, Argentina. \\ E-mail:jrcas@fcnym.unlp.edu.ar,aalmiron@fcnym.unlp.edu.ar
}

\begin{abstract}
A new species of Crenicichla Heckel, $C$. hu, is described from the arroyo Piray-Miní, a left-hand tributary of the río Paraná, Misiones province, Argentina. This new species is easily distinguished from its congeners in the La Plata basin and adjacent coastal rivers by the dark coloration (dark grey or dark brown to black), a color pattern consisting of 7 to 9 black irregular blotches on the flank, and 47-54 scales in the E1 row. Adult females have dorsal fin with an irregular color pattern formed by wide black and white longitudinal stripes and blotches. In addition to standard morphological comparisons, a brief molecular phylogenetic analysis of Crenicichla species from the province of Misiones is also introduced.
\end{abstract}

Key words: molecular phylogeny, systematics, taxonomy, Piray-Miní, ND2, NADH dehydrogenase

\section{Resumen}

Una nueva especie de Crenicichla Heckel, $C$. hu, es descripta del arroyo Piray-Miní, un afluente de la margen izquierda del río Paraná, provincia de Misiones, Argentina. Esta especie es facilmente reconocida entre las especies del género en la Cuenca del Plata y ríos costeros adyacentes por su coloración oscura (gris oscuro o castaño oscuro-negro), un patrón de coloración del flanco con 7 a 9 manchas irregulares negras, 47-54 escamas en la serie E1. Las hembras adultas poseen una aleta dorsal con un patrón de coloración irregular formado por bandas longitudinales y manchas, negras y blancas. Además de una comparación morfológica se presenta un breve análisis filogenético molecular de las especies del género presentes en la provincia de Misiones.

\section{Introduction}

The genus Crenicichla Heckel is the most speciose lineage of Neotropical cichlids. In the present conception the genus includes about 80 valid species (Casciotta et al. 2006; Kullander \& Lucena 2006; Kullander et al. in press) and this number is rapidly increasing (e.g., Casciotta et al. 2006; Kullander \& Lucena 2006; Lucena 2007; Casciotta \& Almirón 2008; Montaña et al. 2008; Kullander 2009). Stawikowski \& Werner (2004) listed more than 120 known species including those yet undescribed. Crenicichla has a widespread distribution, ranging from northern South America to the río Negro in Patagonia, Argentina (Casciotta 1987).

Phylogenetic relationships within Crenicichla are almost unknown and the genus is traditionally divided into several species groups: the C. lugubris group, C. reticulata group, C. saxatilis group, C. wallacii group, and C. lacustris group s.l. (see below); according to some authors, Teleocichla Kullander, is a ingroup of Crenicichla (Kullander 1981, 1982, 1986; Ploeg 1991; Lucena \& Kullander 1992; Kutty 2000; Stawikowski \& Werner 2004; Kullander et al. in press). These species groups are mostly defined by coloration characters, as well as by biogeography as they basically correspond to major river drainages. 
Most Neotropical fish groups have the highest species diversity in the Amazon basin. On the contrary, the diversity of Crenicichla seems to be disproportionately high in the southern part of its distribution (Kullander 2009). At present there are 27 described species and several known but still undescribed from the La Plata basin and adjacent coastal drainages; with a few exceptions all these taxons fall into the above-mentioned $C$. lacustris group s.l. (Stawikowski \& Werner 2004).

A small part (nine described species) of the C. lacustris group s.l. was recently studied by Kullander et al. (in press). With respect to this work, we can divide the group into the following subgroups:

The coastal drainages of Brazil have six endemic species: C. iguapina Kullander \& Lucena, C. lacustris (Castelnau), C. maculata Kullander and Lucena, C. mucuryna von Ihering, C. punctata Hensel, and C. tingui Kullander \& Lucena.

The río Uruguay has 11 endemic or nearly endemic species (the exception is $C$. scottii that enters the lower Paraná) in two species groups or complexes: 1 . The $C$. missioneira group/complex which includes $C$. celidochilus Casciotta, C. empheres Lucena, C. hadrostigma Lucena, C. igara Lucena \& Kullander, C. jurubi Lucena \& Kullander, C. minuano Lucena \& Kullander, C. missioneira Lucena \& Kullander, C. tendybaguassu Lucena \& Kullander; 2. The C. scottii group/complex with C. gaucho Lucena \& Kullander, C. prenda Lucena \& Kullander, C. scottii (Eigenmann).

The río Paraná has eight described endemic species: C. haroldoi Luengo \& Britski, C. iguassuensis Haseman, C. jaguarensis Haseman, C. jupiaensis Britski \& Luengo, C. mandelburgeri Kullander, C. niederleinii (Holmberg), C. tesay Casciotta \& Almirón, and C. yaha Casciotta et al. Another species, $C$. vittata Heckel, occurs both in the Paraná and in the Uruguay drainage basins.

Furthermore, at least three species from other groups of Crenicichla enter the río Paraná drainage. These are $C$. britskii Kullander and C. lepidota Heckel from the C. saxatilis group, and C. semifasciata Heckel from the $C$. reticulata group.

Despite its small size, the province of Misiones is one of the regions with the highest biodiversity in Argentina (Bertonatti \& Corcuera 2000). According to López et al. (2002) Misiones displays the highest rate of endemism of all Argentinean ichthyoregions. The borders of Misiones are defined by three major river drainages of the La Plata system, namely the río Paraná, the río Uruguay and the río Iguazú, each with a different set of species. The location of this small province is thus ideal for the study of faunal evolution in the larger context of the La Plata system.

Recently there have been numerous discoveries of new fish species from Misiones (Miquelarena et al. 2002; Rodríguez \& Miquelarena 2005; Casciotta et al. 2006; Casciotta \& Almirón 2008), including so far two new species of Crenicichla, C. yaha and C. tesay. The aim of this paper is to describe another new species of Crenicichla from the arroyo Piray-Miní belonging to the Paraná basin. We also provide a phylogenetic placement of the new species among Misioneran crenicichlas using molecular markers.

\section{Material and methods}

Morphology. Specimens were cleared and counterstained (C\&S) following the method of Taylor \& Van Dyke (1985). Measurements and counts were taken as described by Kullander (1986). Descriptions of pharyngeal teeth and counts of frashed zone concavities follow Casciotta \& Arratia (1993). Holotype values are indicated by an asterisk. Body length is expressed as standard length (SL). E1 scale counts refer to the scales in the row immediately above that containing the lower lateral line (Lucena \& Kullander 1992).

Institutional abbreviations are as listed in Leviton et al. (1985), except for AI (Asociación Ictiológica, La Plata, Argentina).

Molecular phylogeny. Twenty specimens from eleven localities representing nine prospective species were obtained during a field expedition to Misiones; two additional samples of $C$. lacustris and C. punctata were received commercially from the aquarium trade (Table 1). The mitochondrial gene ND2 (coding the NADH dehydrogenase subunit 2) including adjacent sequences of tRNA (in the order: part of tRNA-Gln, tRNA-Met, ND2, tRNA-Trp, part of tRNA-Ala) was sequenced in order to determine phylogenetic 
relationships. Genomic DNA was extracted from ethanol-preserved gill tissue using a JETQUICK Tissue DNA Spin Kit (Genomed) following the standard protocol. The ND2 gene of ca. $1300 \mathrm{bp}$ was amplified using PCR with the following primers: ILE-5' (CCG GAT CAC TTT GAT AGA GT) and ASN-3' (CGC GTT TAG CTG TTA ACT AA) (Wimberger et al. 1998). Each PCR reaction volume of $25 \mu$ l contained $12.5 \mu 1$ of Combi PPP Master Mix (Top-Bio, http://www.top-bio.cz), $1.5 \mu 1$ of each primer $(10 \mathrm{pmol} / \mu \mathrm{l})$, and $1 \mu 1 \mathrm{of}$ DNA extract. Reaction mixtures were subjected to the following cycling protocol: $10 \mathrm{~min} .95{ }^{\circ} \mathrm{C}, 36 \mathrm{x}(10 \mathrm{~s}$ $96{ }^{\circ} \mathrm{C}, 20 \mathrm{~s} 50{ }^{\circ} \mathrm{C}, 90 \mathrm{~s} 68^{\circ} \mathrm{C}$ ), $10 \mathrm{~min} .72^{\circ} \mathrm{C}$. PCR reactions were performed in a PTC- 150 thermocycler (MJ Research) and PCR products were purified using the JETQUICK PCR Purification Spin Kit (Genomed). Sequencing reactions were performed following the standard protocol with the use of the same primers, and the products were analyzed in an ABI 3730XL automated sequencer (Applied Biosystems; both steps done by Macrogen Inc., Korea). Contiguous sequences of the gene segments were created by assembling DNA strands (forward and reverse) using BioLign 4.0.6.2 (Hall 2001) and aligned manually in BioEdit 7.0.9 (Hall 1999). All sequences were submitted to GenBank under Accession Nos. HM048873, HM048874, GQ328030 to GQ328048 (Table 1).

Separate maximum parsimony (MP) and Bayesian (BA) analyses were performed. Phylogenetic tree construction utilized the software PAUP* 4.0b10 (MP; Swofford 2001) and MrBayes 3.1.2 (BA; Huelsenback \& Ronquist 2001; Ronquist \& Huelsenbeck 2003). For MP analyses heuristic searches were performed to find the most parsimonious tree(s) using tree bisection-reconnection (TBR) branch-swapping and 1000 random sequence addition replicates with equal weight for all sites. Nonparametric bootstrapping (Felsenstein 1985) was used to measure the support of clades with 10000 total pseudoreplicates and TBR branch-swapping with 10 random sequence addition replicates per pseudoreplicate. The phylogenetic tree was rooted with two sequences of Crenicichla lepidota (C7, C34) from the $C$. saxatilis group (see Kullander et al. in press); the outgroup position of $C$. lepidota was further augmented with GenBank sequences of Satanoperca jurupari Heckel (Accession No. AB018971) and Astronotus ocellatus (Agassiz) (AB018972) in the role of an additional outgroup.

Akaike (AIC) criterion was used to select a model for BA analyses in MrModelTest 2.2 (Nylander 2004), a simplified version of ModelTest 3.06 (Posada \& Crandall 1998) for use with MrBayes, and PAUP*. A Bayesian analysis using a Markov chain Monte Carlo simulation was run for 5 million generations, with trees sampled and saved every 100 generations (50000 trees saved per run). Two simultaneous analyses, each with ten chains, were performed using the computational facilities of the Computational Biology Service Unit of Cornell University (http://cbsuapps.tc.cornell.edu). The first trees from each run before reaching equilibrium were discarded as burn-in; convergence between the two runs was estimated using diagnostics criteria produced by the 'sump' command in MrBayes. The remaining trees were used for reconstruction of a 50\% majority-rule consensus tree with the posterior probability (PP) values of the relevant branches displayed by the 'sumt' command.

Uncorrected pairwise divergences were counted in PAUP* with the use of the command 'showdist'.

\section{Results}

\section{Molecular phylogenetic analyses}

Alignment of the 22 sequences of the 1296 bp ND2 region contained 296 parsimony informative characters. MP analysis resulted in one parsimonious tree (Fig. 1; length, 636; CI, 0.74; RI, 0.79) that differs in one node from the consensus tree obtained from BA analysis (model, GTR $+\mathrm{I}+\mathrm{G}$; burn-in, 100). Testing the influence of the burn-in value on the consensus BA tree revealed absolute stability both of the tree topology and of the PP values within the whole investigated range (burn-in 100 to 42000).

The topology and node support of the recovered trees as well as the uncorrected pairwise divergences between relevant clades (Table 2) fully support the taxonomic distinctivness of the new Crenicichla species from the arroyo Piray-Miní. 


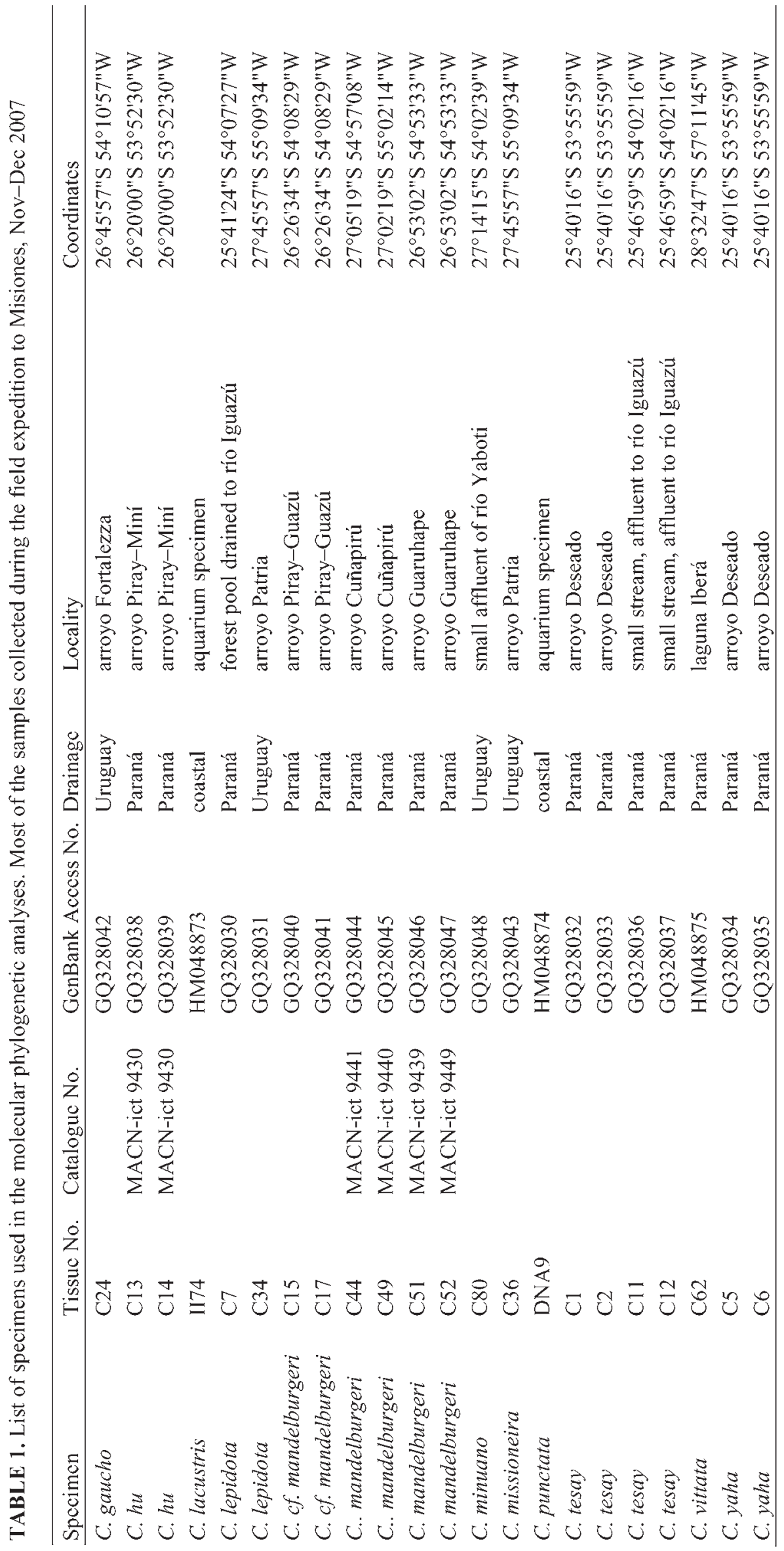




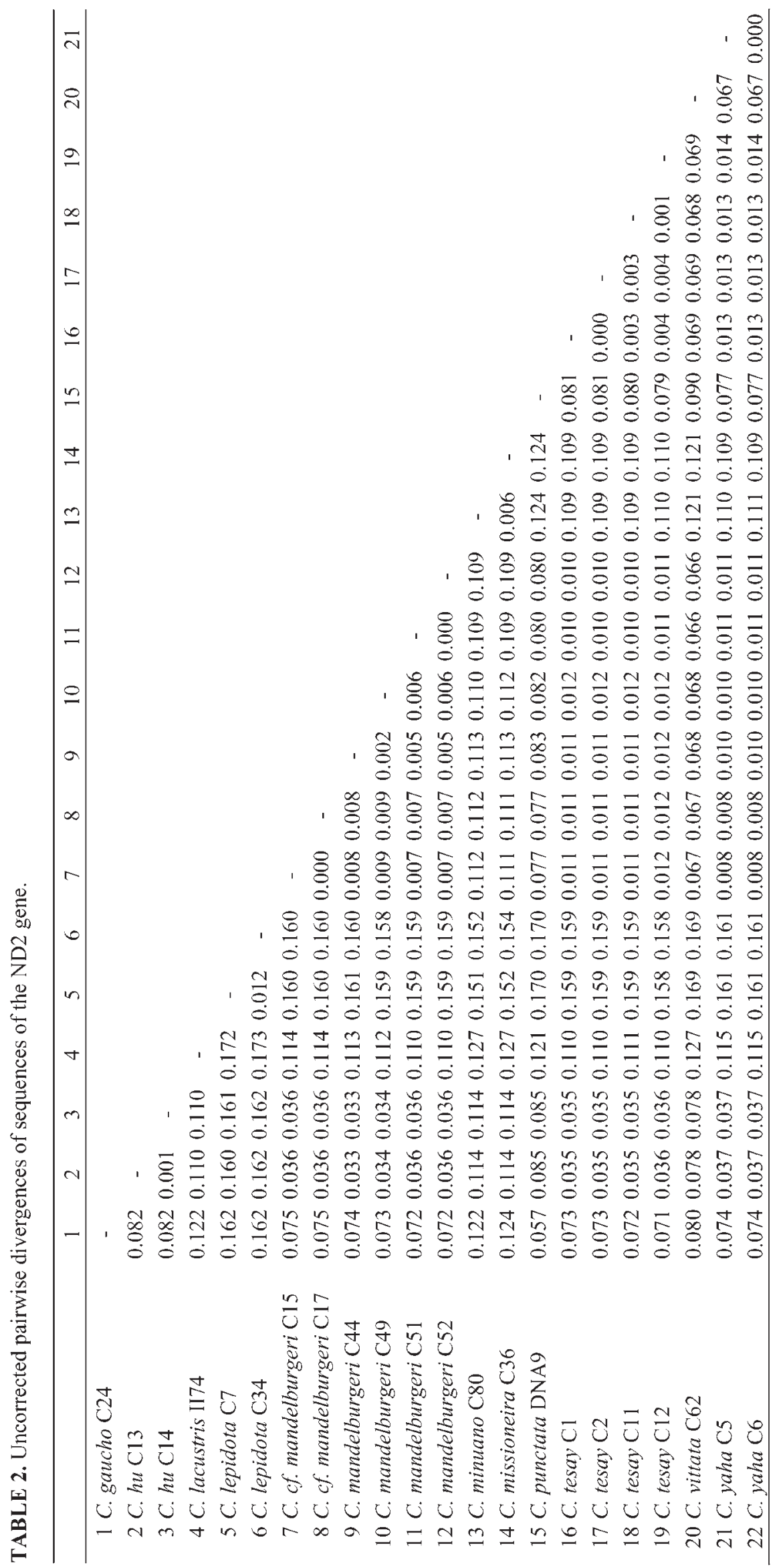




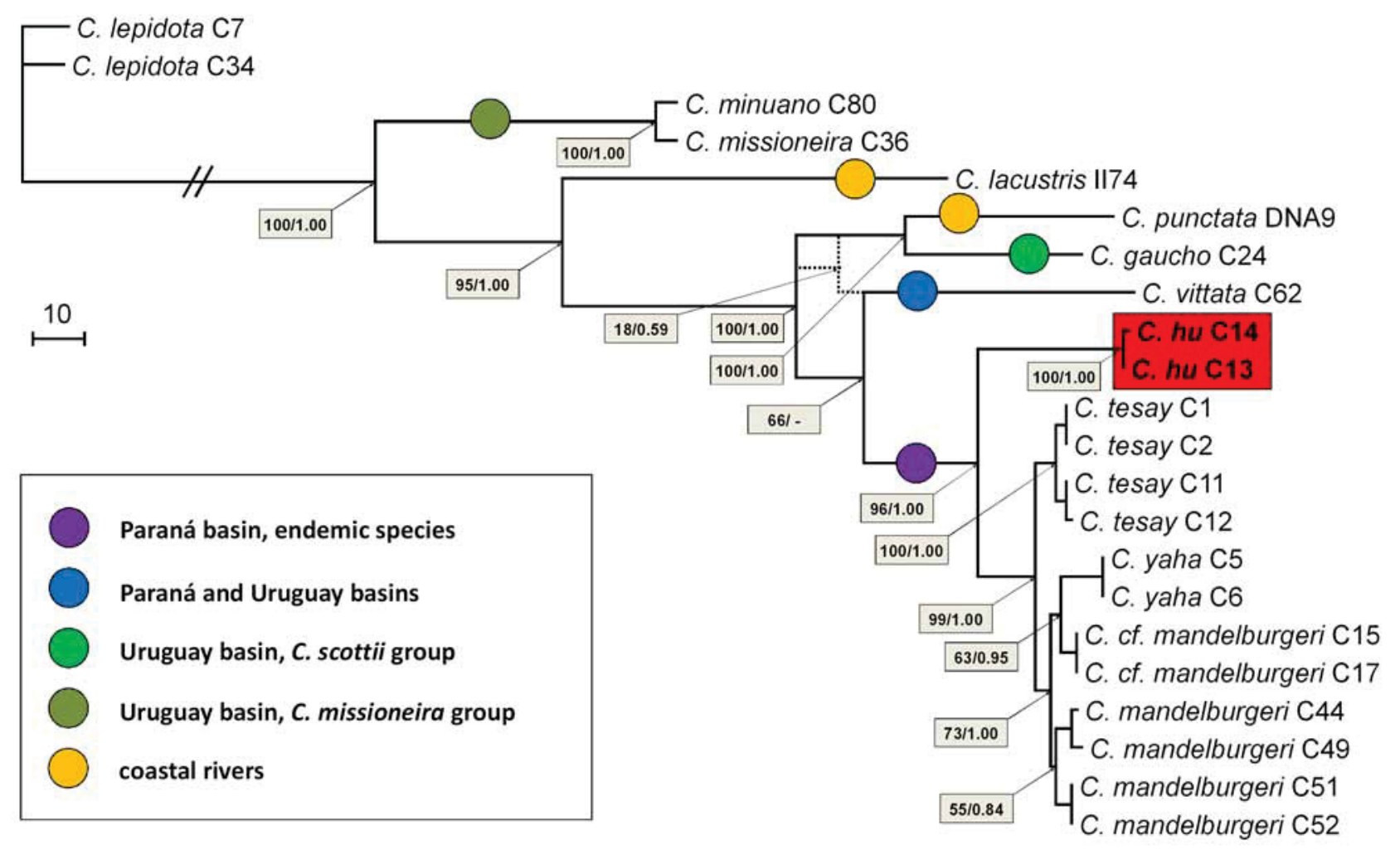

FIGURE 1. Maximum parsimony tree topology based on ND2 sequences; the dotted line displays the different topology of the alternative Bayesian inference. Numbers for each recovered node represent nonparametric bootstrap support (left) and Bayesian posterior probability (right), respectively.

\section{Crenicichla hu, new species}

(Figs. 2-5)

Holotype. MACN-ict 9429, $118.0 \mathrm{~mm}$, Argentina, Misiones, río Paraná basin, arroyo Piray-Miní, 26²0'00.3"S 5352'30.0"W, Nov 2007, O. Říčan et al. (Fig. 2).

Paratypes. All from Argentina, same data as the holotype. MACN-ict 9430, 17 ex., 76.9-153.0 mm. AI 261, 4 ex., 96.3-110.0 mm. AI 262, 1 ex. (C\&S) 93.9 mm, same data as holotype (Figs. 3-4).

Diagnosis. Crenicichla hu is distinguished from all known species of the La Plata basin and adjacent coastal rivers by the following combination of characters: 1. dark grey or dark brown to black color of body and fins, 2.7 to 9 black irregular blotches on the flank, 3. 47-54 scales in row E1, 4. the dorsal fin of adult females with a color pattern formed of black and white longitudinal stripes and/or blotches.

Since the molecular analysis confirmed close relations between $C . h u$ and its biogeographic congeners from the Paraná basin (Fig. 1), a detailed comparative analysis was performed on all 13 known species inhabiting the Paraná drainage basin, either exclusively or partly:

Crenicichla $h u$ is distinguished from C. britskii and C. lepidota (both C. saxatilis group) by the absence of the distinctive humeral spot vs. a humeral spot present (synapomorphy of the group). Crenicichla hu is distinguished from $C$. haroldo $i$ by the absence of dots on lateral line scales vs. brown dots present on each lateral line scale. It differs from C. iguassensis and C. tesay in the absence of small dots on the flank vs. numerous scattered small dots present. Crenicichla $h u$ is distinguished from C. jaguarensis, C. vittata, and adults of $C$. mandelburgeri by the absence of a lateral band vs. a lateral band present. It differs from $C$. jaguarensis in the absence vs. presence of the caudal spot. Further, Crenicichla hu differs from $C$. mandelburgeri and $C$. niederleinii in the absence vs. presence of the narrow vertical double-bars on the flank. It is also distinguished by a low number of scales in a lateral row, 47-54 vs. 56-65 in C. niederleinii and 7885 in C. vittata. Crenicichla hu differs from C. jupiaensis in the absence vs. presence of numerous narrow 
vertical bars on the flank, a well developed (but composed of spots) suborbital stripe vs. reduced to a few spots posteriorly to the orbit, a cheek bearing 4 to 6 scale rows vs. a naked cheek, and the absence vs. presence of a thin black line on the posterior margin of the preopercle. Crenicichla $h u$ lacks several regular parallel rows of small dark spots vs. present in $C$. scottii. The new species is distinguished from C. semifasciata $(C$. reticulata group) by having about half of the caudal fin scaled vs. this fin scaled over most of its surface. $C$. $h u$ further has the ascending arm of the premaxilla longer than the dentigerous one vs. shorter in C. semifasciata. Finally, $C$. $h u$ is distinguished from $C$. yaha by the head depth $17.9-20.8 \%$ vs. $15.1-18.1 \%$ of SL, and lower jaw slightly prognathous vs. jaws isognathous or upper jaw slightly prognathous.

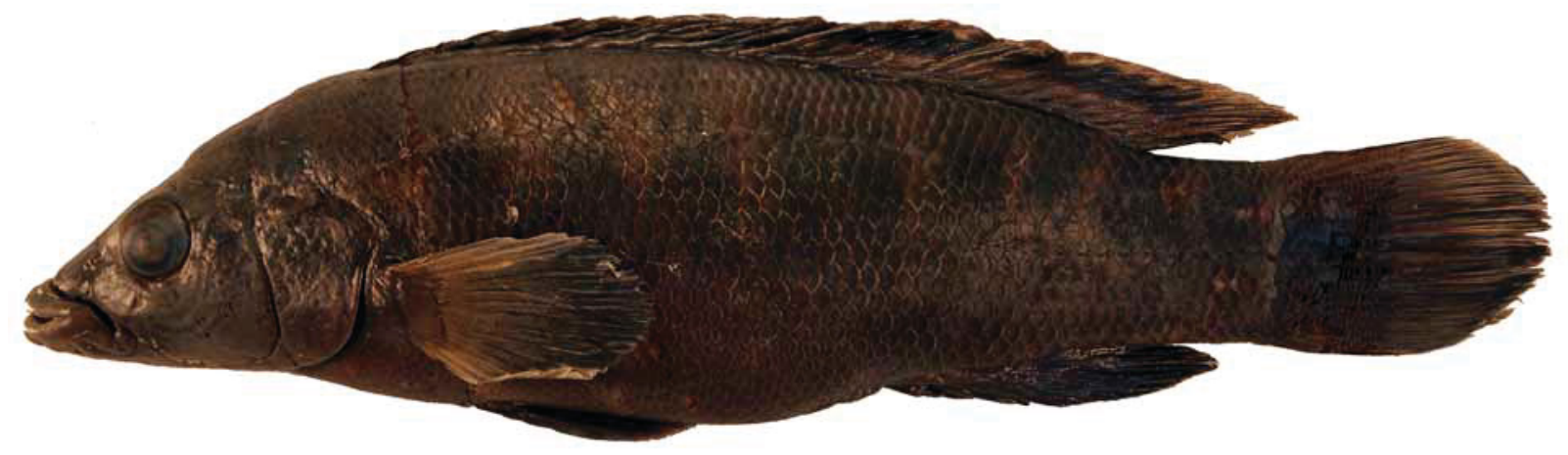

FIGURE 2. Crenicichla $h u$, female, holotype, MACN-ict 9429, $118.0 \mathrm{~mm}$, arroyo Piray-Miní, 26²0'00"S 5352'30"W.

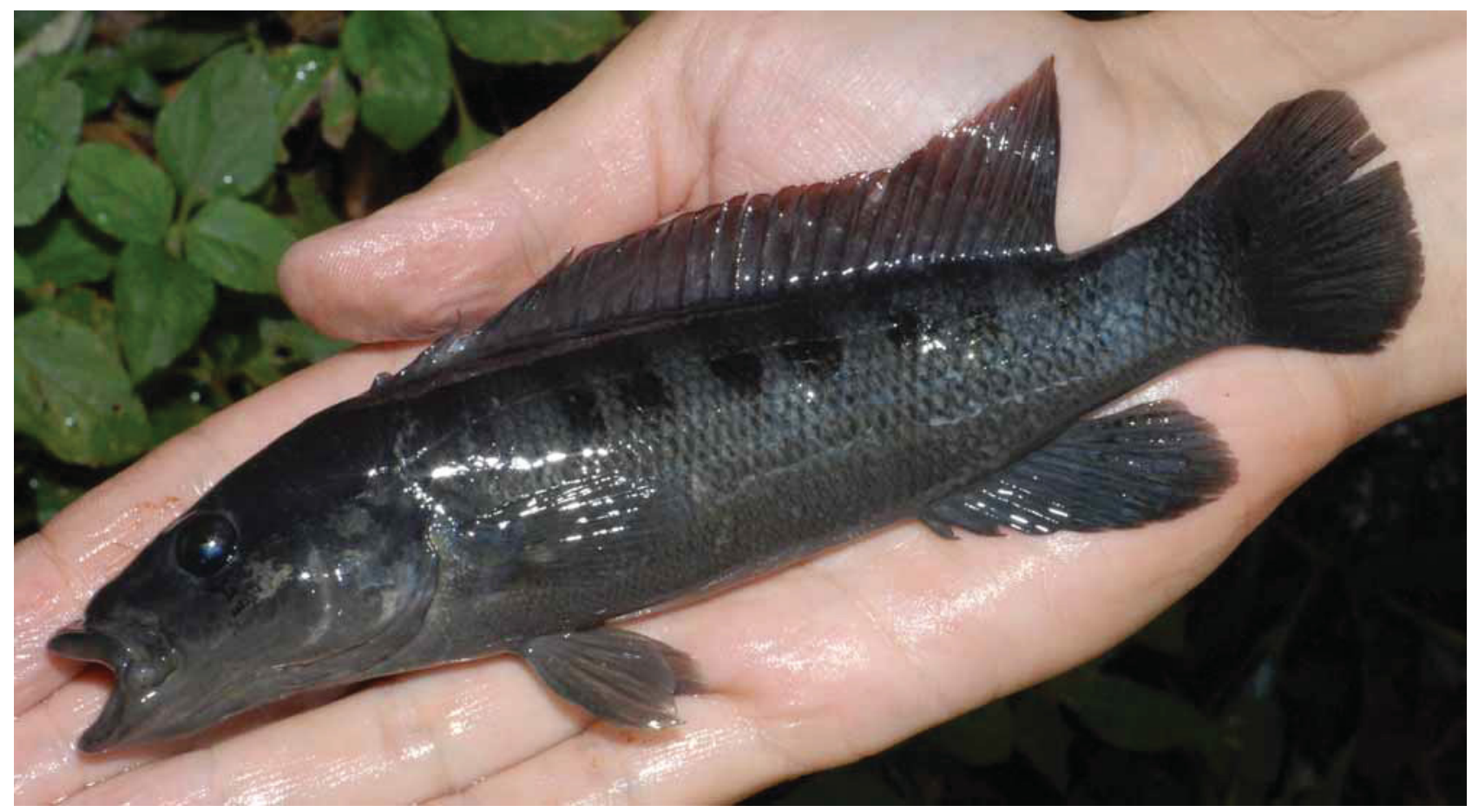

FIGURE 3. Crenicichla hu male, live specimen, paratype, MACN-ict 9430, $153.0 \mathrm{~mm}$.

Description. Morphometric data of the holotype and paratypes is given in Table 3. Body elongate, depth 21.5 to $25.6 \%$ of SL (Fig. 2). Head slightly deeper than wide. Snout short, bluntly pointed in lateral view, 2.5 to 3.0 times in HL. Lower jaw slightly prognathous. Tip of maxilla not reaching anterior margin of orbit in most specimens (reaching in four specimens, MACN-ict 9429). Lower lip widely interrupted medially. Nostrils dorsolateral, nearer anterior margin of orbit than snout tip. Posterior margin of preopercle weakly serrated (21 ex.*) or smooth (3 ex., MACN-ict 9430). Scales on flank strongly ctenoid. Head scales cycloid. Predorsal scales small, superficially embedded in skin. Prepelvic scales smaller than predorsal ones. 
Interopercle naked. Cheek scaled, 4 to 6 scales below eye embedded in skin. Scales in E1 row 47(1), 51(2), 52(4), 53(5), 54(9*). Scales in transverse row 10/14(1), 11/13(1), 11/14(7), 11/15(2), 11/16(3*), 11/17(3), 12/ 13(1), 12/14(2), 12/15(1). Three scale rows between lateral lines. Upper lateral line scales 18(1), 19(1), 21(3), 22(8), 23(4*), 24(2), 25(2). Lower lateral line scales 10(1), 11(7), 12(5), 13(1), 14(5), 15(2*). Dorsal, anal, pectoral and pelvic fins naked. Dorsal fin XVIII,10(1); XX,12(2); XX,13(1); XXI,10(3*); XXI,11(8); XXI, 12(4); XXII,11(1). Anal fin II,10(1); III,8(2); III,9(14*); III,10(3). Pectoral fin 15(10*), 16(11). Caudal-fin squamation extending almost to middle of fin in larger specimens, no more than the basal third of caudal fin in smaller ones. Soft-dorsal fin rounded or pointed tip, surpassing caudal-fin base. Tip of anal fin reaching caudal-fin base (not reaching in three specimens, AI 261 and MACN-ict 9429). Caudal fin rounded. Pectoral fin rounded, almost reaching the tip of pelvic fin. Microbranchiospines present on second through fourth gill arches. Gill rakers externally on first gill arch: 1 on epibranchial, 1 on angle, and 8 on ceratobranchial. Three to five patches of unicuspid teeth on fourth ceratobranchial. Lower pharyngeal tooth plate with unicuspid recurved and curved crenulated bicuspid teeth, those of posterior and medial row larger than remaining ones (Fig. 5). Upper pharyngeal tooth plate with unicuspid and bicuspid teeth. Frashed zone bearing one concavity with small unicuspid teeth. Premaxillary ascending process longer than dentigerous one. Premaxilla with 24(1) unicuspid teeth on outer row, larger than inner ones. Five teeth rows near symphysis. Dentary with 25(1) unicuspid teeth on outer row, 4 rows near symphysis. Total vertebrae 35 (1 C\&S ex.). Premaxillary and dentary outer row teeth slightly movable, inner ones fully depressible.

TABLE 3. Proportional measurements in percents of Standard length of the holotype and 21 paratypes of the new species Crenicichla $h u . \mathrm{SD}=$ standard deviation.

\begin{tabular}{lllll}
\hline & Holotype & Range & Mean & SD \\
\hline Standard length (mm) & 118.0 & $76.9-153.0$ & & \\
Head length & 33.7 & $31.0-35.4$ & 33.4 & 1.18 \\
Snout length & 12.5 & $10.7-13.4$ & 12.0 & 0.75 \\
Head depth & 16.9 & $15.1-18.1$ & 16.2 & 0.74 \\
Body depth & 25.3 & $21.5-25.6$ & 23.2 & 1.24 \\
Orbital diameter & 5.8 & $5.0-7.3$ & 6.2 & 0.54 \\
Interorbital width & 8.6 & $6.7-9.0$ & 7.9 & 0.69 \\
Pectoral fin length & 19.1 & $19.1-23.1$ & 20.5 & 0.92 \\
Caudal peduncle depth & 14.5 & $11.7-14.5$ & 12.9 & 0.60 \\
Caudal peduncle length & 16.8 & $13.8-16.8$ & 15.1 & 0.99 \\
\hline
\end{tabular}

Coloration in alcohol. Background of body deeply dark, almost black in large specimens; smaller ones (75-95 mm) dark brown. Deep grey preorbital stripe between anterior margin of orbit to snout tip, only visible in smaller specimens. Postorbital stripe between posterior margin of orbit to preopercle distal margin, deep grey; only visible in smaller specimens. Suborbital stripe black almost reaching ventral margin of cheek; wide (up to six dots) and fragmented. Flank with 7 to 9 black irregular blotches just below upper lateral line and reaching faintly dorsal-fin base. Posteriormost blotch extending or not onto caudal peduncle. Dorsal, anal, and caudal fins dark grey or black, dorsal and anal fins with numerous dark scattered dots on their surface, also present in caudal fin in smaller specimens. Dorsal fin (females) with an irregular color pattern formed by black and white longitudinal stripes and blotches (3 ex., AI 261 and MACN-ict 9430; Fig. 4) or a black longitudinal stripe (sometimes reduced to a single blotch) with white margin (2 ex.*, MACN-ict 9429; Fig. 2). Caudal fin with a black subcircular spot well separated from base of fin, just above midline of caudal fin. Pectoral and pelvic fins smoky.

Coloration in live specimens. Same as color in alcohol (Figs. 3-4). Live specimens lack almost all carotenoid or physical reflective colors, the overall color is dark grey or dark brown to black. Some female specimens show a faint orange area behind the pectoral fin. Outline of the black areas in the dorsal fin of females milk-colored (Fig. 4). 


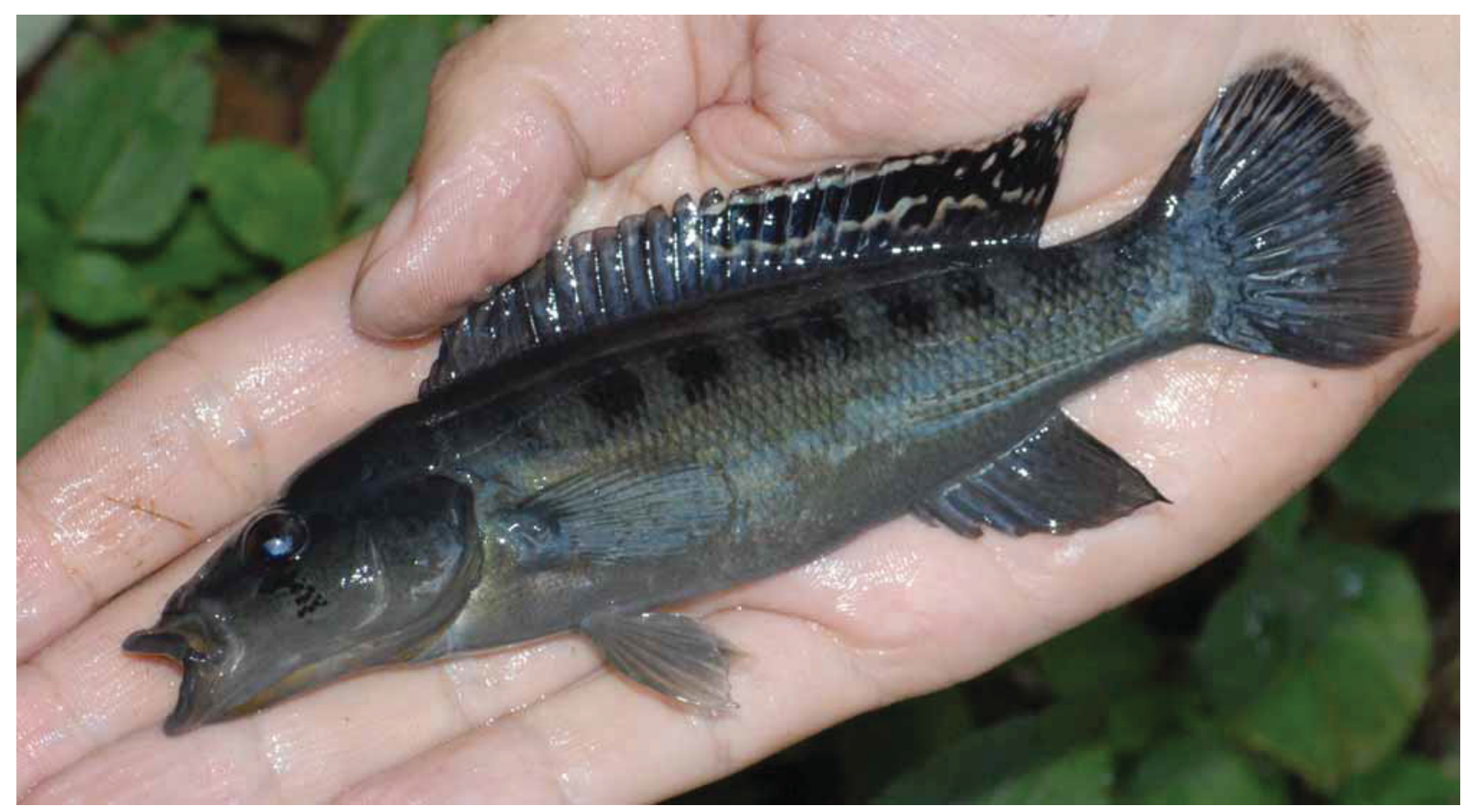

FIGURE 4. Crenicichla hu female, live specimen, paratype, MACN-ict 9430, $122.0 \mathrm{~mm}$.

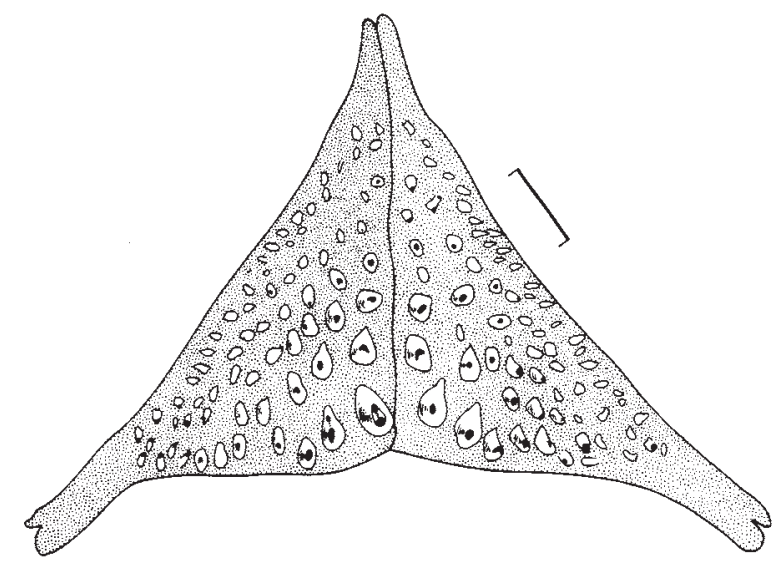

FIGURE 5. Crenicichla hu, lower pharyngeal tooth plate in occlusal view, AI 262, $93.9 \mathrm{~mm}$ SL. Scale bar: $1 \mathrm{~mm}$.

Ecological notes. The arroyo Piray-Miní (the type and only-known locality) has clear and rapidly flowing water. The depth of the arroyo Piray-Miní is variable, 0.20 to $1.40 \mathrm{~m}$. The bottom consists of mud, sand, and mostly stones. Some areas have scarce submerged vegetation (Figs. 6-7).

Etymology. The specific epithet hu is a Guaraní word $h \hat{u}$ that means black in allusion to the ground color of the body and fins.

Discussion. Molecular phylogeny divides the Misioneran crenicichlas into several clades (Fig.1). The basal-most species is C. lepidota (C. saxatilis group; Fig. 1; tree additionaly rooted with Satanoperca jurupari and Astronotus ocellatus; see Methods). The two philosophically distinct computing methods (MP, BA) inferred a robust phylogenetic hypothesis of nearly identical topologies that supports the biogeographic foundation of the recognized species groups. All species from the Misioneran part of the Parana drainage basin (C. hu, C. tesay, C. yaha, and C. mandelburgeri) were grouped together in one clade with conclusively high support (Fig. 1; Paraná endemic species; bootstrap, 96; PP, 1.00). The newly described Crenicichla hu is recovered in a basal position of this clade. Crenicichla mandelburgeri appears non-monophyletic (see below). 
The position of $C$. vittata inhabiting both the Paraná and the Uruguay basins differs between the BA and MP hypotheses, in the latter forming a monophyly together with the endemic Paraná species (Fig. 1; bootstrap, 66). The morphologically distinct Crenicichla species from the Uruguay basin formed two independent clades (Fig. 1; C. missioneira and C. scottii groups). Two species from the coastal rivers (C. lacustris, C. punctata) do not form a monophyletic lineage in either of the two phylogenies.

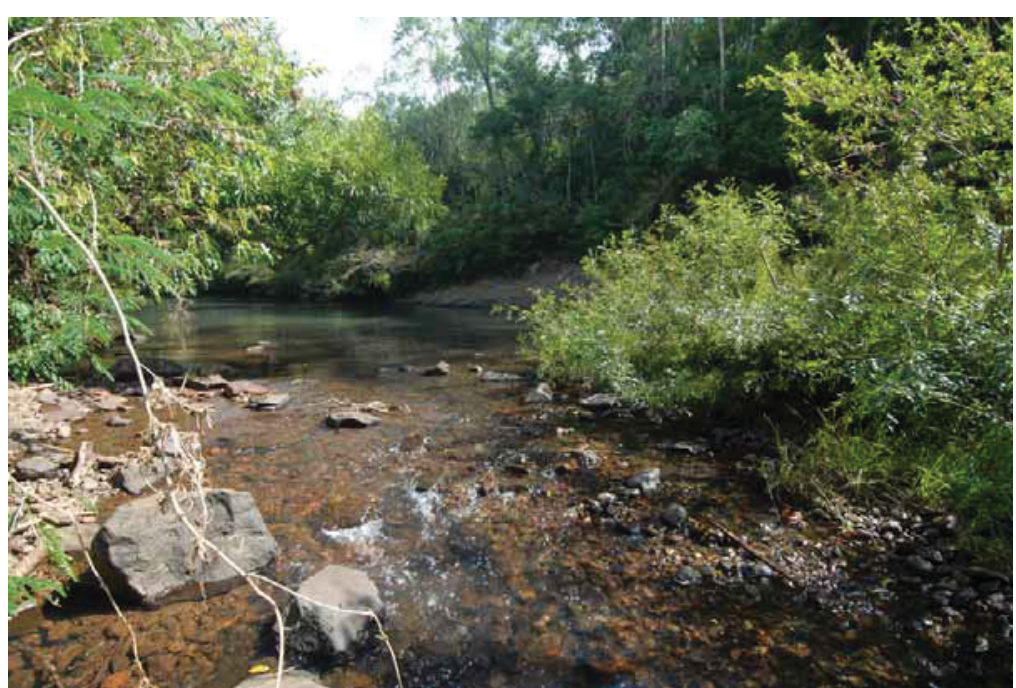

FIGURE 6. Arroyo Piray-Miní, the type locality of Crenicichla hu.

The phylogeny of a few species of Crenicichla from southern South America was recently studied by Kullander et al. (in press). That study supports virtually the same relationships between the above-mentioned clades. The endemic Paraná species group was represented in their analysis by only one taxon $(C$. iguassuensis) as were the coastal-river drainages (C. punctata). The Uruguay basin was represented by the $C$. scottii group (C. scottii) and the C. missioneira group (C. missioneira, C. minuano, C. celidochilus, C. empheres, $C$. tendybaguassu). There is thus no overlap with our taxon sampling of the endemic Paraná clade.

Evaluating the uncorrected pairwise divergences between the gene sequences of Crenicichla hu and the other species, the supposed higher evolutionary rate in the Geophagini tribe of cichlids must be taken in account (Farias et al. 1999, 2000; Pereyra \& García 2008). Referring to ND2 sequences, the lowest divergence between a haplotype of $C$. $h u$ and a haplotype of the nearest species $(C$. mandelburgeri $\mathrm{C} 44)$ is $3.3 \%$ (Table 2). On the other hand, substantially lower values of divergences between formerly described species can be found (e.g., C. missioneira $\mathrm{C} 36$ vs. C. minuano $\mathrm{C} 80,0.6 \%$; C. tesay $\mathrm{C} 1$ vs. C. mandelburgeri C51, 1.0\%; C. yaha C5 vs. C. mandelburgeri C44, 1.0\%). Despite the little-known divergence rate in Geophagini (López-Fernández et al. 2005), molecular divergences between the newly described species and its phylogenetic neighbours are substantial.

With the newly described $C$. $h u$, fourteen species of Crenicichla have now been recorded from the río Paraná basin. Some of them (i.e. C. britskii, C. haroldoi, and C. jaguarensis) are restricted to the Upper Paraná basin (Resende 2003; Reis et al. 2003). Crenicichla jupiaensis and C. niederleinii are found both in the Upper and Middle Paraná basin. Several species (i.e. C. lepidota, C. mandelburgeri, C. scottii, C. semifasciata and C. vittata) inhabit only the lower-middle part of the river; $C$. vittata occurs also in the Uruguay basin. Crenicichla iguassuensis and C. tesay are only present in the Iguazú basin. Crenicichla yaha is registered from the arroyo Urugua-í (Paraná basin) and Iguazú basin above the Cataratas del Iguazú.

The high diversity of ichthyofauna in the Argentinean province of Misiones has already been stressed. Three new Crenicichla species have recently been described from the río Paraná tributaries in Misiones $(C$. yaha, C. tesay, and C. $h u$ ), and several additional putatively new species are known to us from these tributaries (pers. obs).

We also confirm the presence of Crenicichla mandelburgeri in Misiones. Our material was compared with material from the type localities of $C$. mandelburgeri (both morphology and the ND2 gene sequences; not 
shown). This taxon, however, demonstrates geographical variation as well as phylogeographic structure (Fig. 1), and we thus cannot rule out the presence of a species complex; the specimens from Piray-Guazu (haplotypes $\mathrm{C} 15, \mathrm{C} 17$ ) that infringe on the monophyly of this species are therefore referred to as $C$. $c f$. mandelburgeri.



FIGURE 7. Hydrological map of the Province of Misiones. The type locality is marked with a solid circle.

Based on our field observations, Crenicichla missioneira, C. minuano and C. gaucho, described from the Middle río Uruguay in Rio Grande do Sul, Brazil and also cited by Lucena \& Kullander (1992) from 
Misiones, are quite common in the río Uruguay tributaries in Misiones. Crenicichla hadrostigma, described from the Upper río Uruguay in Santa Catarina, Brazil is known so far from one locality in Misiones (Lucena 2007), confirming the possibility of finding additional Upper Uruguay Crenicichla species in Misiones. On this note, Lucena \& Kullander (1992) also cite C. tendybaguassu from Misiones.

So far there are no records in Misiones of four Crenicichla species which are known from the Upper río Uruguay basin in Brazil (C. prenda, C. empheres, C. igara and C. jurubi), whose boundary with the Middle río Uruguay is recognised as being at the Salto Moconá (Yucumã), just downstream from the río Pepirí-Guazú which forms the eastern border between Misiones, Argentina and Santa Catarina, Brazil (Zaniboni Filho \& Schulz 2003). The ranges of these species could thus primarily be outside of Misiones as they are also not known from the Middle río Uruguay in Rio Grande do Sul, Brazil. However, the presence of these species in Misiones cannot be ruled out (see C. hadrostigma and C. tendybaguassu above).

Despite its small size, the province of Misiones shows biogeographic structuring which cannot be explained merely by diversity on a broader scale. Both the río Paraná and río Uruguay tributaries in Misiones are divided from the main rivers by waterfalls close to their mouths, but the northern tributaries of the Paraná in particular and the Iguazú itself in Misiones have a significant number of endemics which are so far not known outside of Misiones (i.e. Paraguay or Brazil). Among Crenicichla these are C. tesay from río Iguazú and $C$. yaha from río Iguazú and arroyo Urugua-í and $C$. $h u$ from arroyo Piray-Miní (Fig. 7). Two putative new species are further known from the arroyo Urugua-í (pers. obs.), which is located between the río Iguazú and arroyo Piray-Miní. These three drainages together with arroyo Aguaray-Guazú form the northern part of Misiones. From the southeastern-most point of this part of Misiones starts the watershed between the río Paraná and río Uruguay. Tributaries of the río Paraná from here to the southeast (starting with arroyo PirayGuazú, Fig. 7) have a diferent fauna of Crenicichla (dominated by C. mandelburgeri). A very similar pattern is also observed among Australoheros Ŕíčan \& Kullander, but with the exception that south from arroyo Piray-Miní there are so far no known species of Australoheros in the río Paraná tributaries in Misiones $(A$. kaaygua Casciotta et al., A. tembe (Casciotta et al.) [and likely A. guarani Ŕ Ričan \& Kullander] are known again only from the northern tributaries).

Comparative material. A list of comparative material of C. scottii and C. vittata is available in Casciotta (1987). In addition, the following material was studied: Crenicichla hadrostigma: Argentina. AI 220, 1 ex., $72.8 \mathrm{~mm}$, Misiones, Itacaruare, río Uruguay basin. Crenicichla iguassuensis: Brasil. FMNH 54159 (holotype), 137 mm, Porto Uniao da Victoria, Rio Iguassu. Crenicichla jupiaensis: Argentina. AI 226, 2 ex., 87.7-93.0 mm, Corrientes, río Paraná at Yahapé. AI 227, 1 ex., $60.7 \mathrm{~mm}$, Corrientes, río Paraná at Yahapé. Crenicichla lepidota: Argentina. MACN-ict 5067, 4 ex., 67.7-113.4 mm, Misiones, Represa Estación Experimental Cerro Azul. FML 00528, 1 ex., 111.5 mm, Salta, Luna Muerta, Hickman. MACN-ict 3656, 2 ex., 116.0-165.7 mm, Formosa, Riacho de Oro. MACN-ict 7275, 1 ex., 151.6 mm, Chaco, Esteros del Palmar. FML 00312, 1 ex., 138.0 mm, Corrientes, Isla Apipé Grande, Ituzaingó. MACN-ict 4091, 1 ex., 98.4 mm, Entre Ríos, río Uruguay, Concepción del Uruguay. MACN-ict 2314, 6 ex., 59.9-104.2 mm, Buenos Aires, Isla Martín García. Uruguay. MNHNM 2087, 1 ex., $72.9 \mathrm{~mm}$, Departamento Colonia, arroyo Limetas. Crenicichla cf. mandelburgeri: MACN-ict 9439, 2 ex., 83.7-93.0 mm, Misiones, arroyo Guaruhape en ruta 220, río Paraná basin. MACN-ict 9440, 2 ex., 72.6-82.3 mm, Misiones, arroyo Cuñapirú, in route 223 near Ruiz de Montoya, río Paraná basin. MACN-ict 9441, 7 ex., 56.0-93.0 mm, Misiones, arroyo Cuñapirú (arroyo Tucangua), río Paraná basin. MACN-ict 9442, 2 ex., 102.2-208 mm, Misiones, arroyo Chapa, ruta 6, río Paraná basin. Boggiana ocellata: Paraguay. MSNG 33700 (holotype), 257.5 mm, Puerto 14 de Mayo, Bahía Negra, Chaco Boreal. Crenicichla semifasciata: Argentina. MACN-ict 3683, 1 ex., 68.8 mm, Formosa, Riacho de Oro. MACN-ict 6239, 1 ex., 176,6 mm, Entre Ríos, arroyo Curupí. Crenicichla tesay: MACN-ict 9016 (holotype), $115.1 \mathrm{~mm}$, Argentina, Misiones, río Iguazú basin, arroyo Verde. Crenicichla yaha: Argentina, Misiones. MACN-ict 8924 (holotype), 103.7 mm, arroyo Urugua-í in Isla Palacios. AI 199, 1 ex., 116.6 mm, río Iguazú basin, arroyo Benavente. MTD-F 30606 (paratype), 1 ex., $105.9 \mathrm{~mm}$, arroyo Urugua-í in ruta provincial 19, Parque Provincial Islas Malvinas. AI 200 (paratype), 1 ex., $135.8 \mathrm{~mm} \mathrm{SL}$, arroyo Uruzú (affluent of A. Urugua-1́) in ruta provincial 19, Parque Provincial Islas Malvinas. AI 202 (paratypes), 4 ex., 1 (C\&S) 37.4$48.5 \mathrm{~mm}$, arroyo Urugua- -1 in Isla Palacios. 


\section{Acknowledgments}

We are grateful to Štěpánka Hulová and Jan Štefka, both from the University of South Bohemia, for their kind help and assistance during the field expedition. David Hardekopf read the manuscript and revised the English. Carlos Tremouilles helped us with the figures. Financial support was provided by the research project MSM6007665801 of the Czech Ministry of Education, the GAČR 206/08/P003 grant (Czech Science Foundation) and a DCG grant (Deutsche Cichliden-Gesellschaft) to O. ̌̌. Part of this work was carried out by using the resources of the Computational Biology Service Unit from Cornell University which is partially funded by the Microsoft Corporation.

\section{References}

Bertonatti, C. \& Corcuera, J. (2000) Situación Ambiental Argentina. Fundación Vida Silvestre, Buenos Aires, 400 pp.

Casciotta, J.R. (1987) Crenicichla celidochilus n. sp. from Uruguay and a multivariate analysis of the lacustris group (Perciformes, Cichlidae). Copeia, 1987, 883-891.

Casciotta, J. \& Almirón, A. (2008) Crenicichla tesay, a new species of cichlid (Perciformes: Labroidei) from the río Iguazú basin in Argentina. Revue suisse de Zoologie, 115, 651-659.

Casciotta, J.R., Almirón, A.E. \& Gómez, S.E. (2006) Crenicichla yaha sp. n. (Perciformes: Labroidei: Cichlidae), a new species from the río Iguazú and arroyo Urugua-í basins, northeastern Argentina. Zoologische Abhandlungen, Staatliche Naturhistorische Sammlungen Dresden, Museum für Tierkunde, 56, 107-112.

Casciotta, J.R. \& Arratia, G. (1993) Jaws and teeth of American Cichlids (Pisces: Labroidei). Journal of Morphology, $217,1-36$.

Farias, I.P., Ortí, G. \& Meyer, A. (2000) Total evidence: molecules, morphology, and the phylogenetics of cichlid fishes. Journal of Experimental Zoology, 288, 76-92.

Farias, I.P., Ortí, G., Sampaio, I., Schneider, H. \& Meyer, A. (1999) Mitochondrial DNA phylogeny of the family Cichlidae: monophyly and fast molecular evolution of the Neotropical assemblage. Journal of Molecular Evolution, 48, 703-711.

Felsenstein, J. (1985) Confidence limits on phylogenies: an approach using the bootstrap. Evolution, 39, $783-791$.

Hall, T.A. (1999) BioEdit: a user-friendly biological sequence alignment editor and analysis program for Windows 95/ 98/NT. Nucleic Acids Symposium Series, 41, 95-98.

Hall, T.A. (2001) Biolign alignment and multiple contig editor. Available from: http://en.bio-soft.net/dna/BioLign.html (accessed 19 June 2009).

Huelsenbeck, J.P. \& Ronquist, F. (2001) MrBayes: Bayesian inference of phylogenetics trees. Bioinformatics, 17, 754755.

Kullander, S.O. (1981) Cichlid fishes from the La Plata basin. part I. Collections from Paraguay in the Muséum d'Histoire naturelle de Genève. Revue suisse de Zoologie, 88, 675-692.

Kullander, S.O. (1982) Cichlid fishes from the La Plata basin. Part 3. The Crenicichla lepidota species group (Teleostei: Cichlidae). Revue suisse de Zoologie, 89, 627-661.

Kullander, S.O. (1986) Cichlid fishes of the Amazon River drainage of Peru. Swedish Museum of Natural History, Stockholm, $431 \mathrm{pp}$.

Kullander, S.O. (2009) Crenicichla mandelburgeri, a new species of cichlid fish (Teleostei: Cichlidae) from the Paraná River drainage in Paraguay. Zootaxa, 2006, 41-50.

Kullander, S.O. \& Lucena, C.A.S. (2006) A review of the species of Crenicichla (Teleostei: Cichlidae) from the Atlantic coastal rivers of southeastern Brasil from Bahia to Rio Grande do Sul State, with description of three new species. Neotropical Ichthyology, 4, 127-146.

Kullander, S.O., Norén, M., Friðriksson, G.B. \& Lucena, C.A.S. (in press) Phylogenetic relationships of species of Crenicichla (Teleostei: Cichlidae) from southern South America based on the mitochondrial cytochrome $b$ gene. Journal of Zoological Systematics and Evolutionary Research, doi 10.1111/j.1439-0469.2009.00557.x.

Kutty, V. (2000) An introduction to the pike cichlids of the genus Crenicichla. Cichlid News, 9, 6-14.

Leviton, A.E., Gibbs Jr., R.H., Heal, E. \& Dawson, C.E. (1985) Standards in herpetology and ichthyology: Part I. Standard symbolic codes for institutional resource collections in herpetology and ichthyology. Copeia, 1985, 802832.

López, H.L., Morgan, C.C. \& Montenegro, M.J. (2002) Ichthyological ecoregions of Argentina. Probiota: Serie Documentos $\mathrm{N}^{\circ}$, La Plata, Buenos Aires, Argentina, 53 pp.

López-Fernández, H., Honeycutt, R.L. \& Winemiller, K.O. (2005) Molecular phylogeny and evidence for an adaptive radiation of geophagine cichlids from South America (Perciformes: Labroidei). Molecular Phylogenetics and 
Evolution, 34, 227-244.

Lucena, C.A.S. (2007) Two new species of the genus Crenicichla Heckel, 1840 from the upper rio Uruguay drainage (Perciformes: Cichlidae). Neotropical Ichthyology, 5, 449-456.

Lucena, C.A.S. \& Kullander, S.O. (1992) The Crenicichla (Teleostei: Cichlidae) species of the Uruguai River drainage in Brazil. Ichthyological Exploration of Freshwaters, 3, 97-160.

Miquelarena, A.M., Protogino, L.C., Filiberto, R. \& López, H.L. (2002) A new species of Bryconamericus (Characiformes: Characidae) from the Cuña-Pirú creek in north-eastern Argentina, with comments on accompanying fishes. Aqua, Journal of Ichthyology and Aquatic Biology, 6, 69-82.

Montaña, C.G., López-Fernández, H. \& Taphorn, D.C. (2008) A new species of Crenicichla (Perciformes: Cichlidae) from the Ventuari River, Upper Orinoco River basin, Amazonas State, Venezuela. Zootaxa, 1856, 33-40.

Nylander, J.A.A. (2004) MrModeltest, Evolutionary Biology Centre, Uppsala Univ, Sweden. Available from: http:// www.abc.se/ nylander (accessed 19 June 2009).

Pereyra, S. \& García, G. (2008) Patterns of genetic differentiation in the Gymnogeophagus gymnogenys species complex, a neotropical cichlid from South American basins. Environmental Biology of Fishes, 83, 245-257.

Ploeg, A. (1991) Revision of the South American cichlid genus Crenicichla Heckel, 1840, with description of fifteen new species and consideration on species groups, phylogeny and biogeography (Pisces, Perciformes, Cichlidae). Univ. Amsterdam, Netherlands, 153 pp.

Posada, D. \& Crandall, K.A. (1998) Modeltest: testing the model of DNA substitution. Bioinformatics, 14, 817-818.

Reis, R.E., Kullander, S.O. \& Ferraris Jr., C.J. (2003) Check list of the freshwater fishes of South and Central America. Edipucrs, Porto Alegre, Brazil, 729 pp.

Resende, E.K. (2003) Migratory Fishes of the Paraguay-Paraná Basin, Excluding the Upper Paraná Basin. In: Carolsfeld, J., Harvey, B., Ross, C. \& Baer, A. (Eds.), Migratory fishes of South America: Biology, Fisheries and Conservation Status. International Development Research Center and The World Bank, pp. 99-156.

Rodríguez, M.S. \& Miquelarena, A.M. (2005) A new species of Rineloricaria (Siluriformes: Loricariidae) from the Paraná and Uruguay River basins, Misiones, Argentina. Zootaxa, 945, 1-15.

Ronquist, F. \& Huelsenbeck, J.P. (2003) Mrbayes 3: Bayesian phylogenetic inference under mixed models. Bioinformatics, 19, 1572-1574.

Stawikowski, R. \& Werner, U. (2004) Die Buntbarsche Amerikas. Band 3: Erdfresser, Hecht- und Kammbuntbarsche. Eugen Ulmer, Stuttgart, 478 pp.

Swofford, D.L. (2001) Paup*. Phylogenetic Analysis Using Parsimony (*and Other Methods), Sinauer Associates, Inc. Publishers, Sunderland, Massachusetts. Available from: http://paup.csit.fsu.edu (accessed 19 June 2009).

Taylor, W.R. \& Van Dyke, G.C. (1985) Revised procedures for staining and clearing small fi shes and other vertebrates for bone and cartilage study. Cybium, 9, 107-119.

Wimberger, P.H., Reis, R.E. \& Thornton, K.R. (1998) Mitochondrial Phylogenetics, Biogeography, and Evolution of Parental Care and Mating Systems in Gymnogeophagus (Perciformes: Cichlidae). In: Malabarba L.R., Reis, R.E., Vari, R.P., Z. M. S. Lucena \& C. A. S. Lucena (Eds.), Phylogeny and Classification of Neotropical fishes. Porto Alegre, Edipucrs, pp. 69-84.

Zaniboni Filho, E. \& Schulz, U.H. (2003) Migratory fishes of the Uruguay river. In: Carolsfeld, J., Harvey, B., Ross, C. \& Baer, A. (Eds.), Migratory fishes of South America: Biology, Fisheries and Conservation Status. International Development Research Center and The World Bank, pp. 157-194. 